\title{
USING SOLAR ENERGY FOR PUPMING WATER IN SPRINKLER IRRIGATION SYSTEM
}

\author{
Yassen H. Y. AL-Tahan*
}

\begin{abstract}
Ninevah governorate is situated at north of Iraq. The total cropped area of this region is about 4000000 hectars, the land is very fertile. The major crops are wheat and barley, and around this area about $71 \%$ of the country's wheat and $41 \%$ barley are grown, all depending on rainfalls.

Due to insufficient precipitation during the last ten years. Most of the farmers did not harvest their crops for many years and they left their villages and fields. Surface water and electricity is not available in this district. Sprinkler irrigation system is designed depending to underground water from wells using solar energy for pumping. The sprinkler system can be used as supplementary irrigation with winter crops (wheat and barely) and giving a chance of planting other crops during the summer season. This will maximize the crop production many times. Cost of the system is analyzed and discussed.
\end{abstract}

\section{INTRODUCTION}

raq is situated between the latitudes of 32.25 and $29.50 \mathrm{E}$ and the
longitude of 48.45 and $38.45 \mathrm{~N}$ and covering area of 438.45 square
kilometers.

This area was one of the most abundantly irrigated area in the world. The major crops in Iraq are wheat and barley, which are planted in the north part of Iraq,

*College of Agriculture and Forestry, Mosul University, Iraq 
Fig. 1. All depending on the rainfalls. The total cropped area of this region (AL- Jazeera district) is about 4000000 hectars (AL-Fakhry; 1974). The crop production per unit area is very low because of the desertification of this area, and to insufficiency and infrequency of rainfall.

The rainfall here not only fluctuates as to quantity and distribution within one season but also but also from year to year, Table 1 .

In order to maximize the agricultural production in this district it is necessary to construct a good supplementary irrigation system.

Due to the desertification of this region and with no yield of the planted crops for the last decade at all, most of the farmers left their villages and fields searching for other source of financing their life.

There is no surface water neither electricity sources in this district. But there is a plenty of under ground water.

The present study is aimed to design sprinkler irrigation system supplied water by deep well and electricity from solar energy and finally to overcome the desertification phenomenon in the region.

\section{MATERIALS AND METHODS}

\section{Location of the Project and It's Climatical Condition:}

The project is located in Ninevah governorate north of Iraq, Fig. 1. Ninevah's area is characterized by semi-arid Mediterranean Climate, (Choudhury et al. 1977), with scanty precipitation ranging from $200 \mathrm{~mm}$ to $350 \mathrm{~mm}$, almost all falling during months from October to May, and is followed by hot dry summer. Temperature varies widely in this region, Table 1. July and August are the warmest months in which the mean daily temperature is more than $42.1^{\circ} \mathrm{c}$ and January is the coldest month $2.8^{\circ} \mathrm{c}$. Clear skies predominate the days and permit a large amount of solar energy to reach the earth. 
In this area the type of soil is heavy clay.

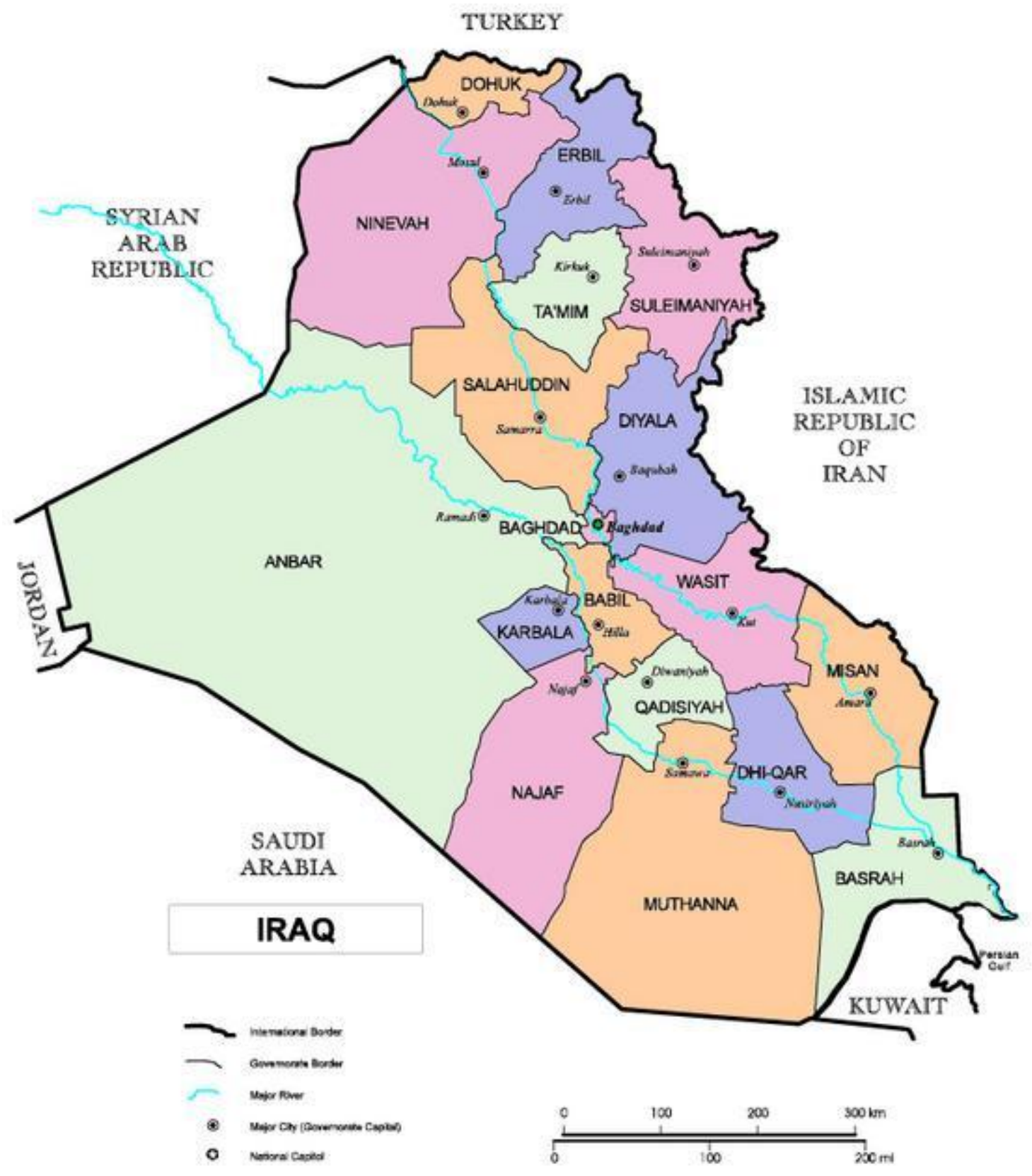

Fig.1 Map of Iraq 
Table. 1. Meteorological data for calculating evapotranspiration.

Source: Mosul meteorological station, Iraq.

\begin{tabular}{|c|c|c|c|c|c|c|c|c|c|}
\hline \multirow{2}{*}{ Months } & \multicolumn{3}{|c|}{ Temperature ${ }^{\circ} \mathrm{c}$} & \multirow{2}{*}{$\begin{array}{c}\text { Rainfall, } \\
\text { mm }\end{array}$} & \multirow{2}{*}{$\begin{array}{c}\text { Relative } \\
\text { humidity, } \\
\%\end{array}$} & \multirow{2}{*}{$\begin{array}{c}\text { Wind } \\
\text { speed at } \\
\text { 2meters, } \\
\text { m/sec }\end{array}$} & \multirow{2}{*}{$\begin{array}{c}\text { Sun } \\
\text { shine, } \\
\text { hr }\end{array}$} & \multirow{2}{*}{$\begin{array}{c}\text { Solar } \\
\text { radiation, } \\
\text { Cal./cm }^{2}\end{array}$} & \multirow{2}{*}{$\begin{array}{c}\text { Potential } \\
\text { evapotrans- } \\
\text { piration } \\
\text { Etp, mm }\end{array}$} \\
\hline & Min. & Max. & Mean. & & & & & & \\
\hline 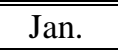 & 2.8 & 13.9 & 8.35 & 76.35 & 81 & 1.4 & 4.76 & 5545 & 0.9 \\
\hline Feb. & 4.3 & 15.3 & 9.80 & 59.70 & 73 & 1.6 & 5.66 & 7867 & 1.6 \\
\hline Mar. & 7.8 & 20.8 & 14.30 & 48.20 & 67 & 1.9 & 7.1 & 13225 & 3.2 \\
\hline Apr. & 12.4 & 25.5 & 18.95 & 32.50 & 65 & 2.2 & 7.6 & 14032 & 4.4 \\
\hline May. & 16.1 & 32.6 & 24.35 & 7.20 & 45 & 2.5 & 10.2 & 19618 & 7.4 \\
\hline Jun. & 19.4 & 38.6 & 29.00 & 0 & 27 & 2.3 & 12.7 & 20104 & 9.1 \\
\hline Jul. & 22.5 & 42.1 & 31.85 & 0 & 26 & 2.3 & 12.1 & 20056 & 9.5 \\
\hline Aug. & 21.3 & 41.2 & 31.25 & 0 & 28 & 2.0 & 11.8 & 17830 & 8.6 \\
\hline Sep. & 19.8 & 38.4 & 29.10 & 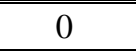 & 32 & 1.9 & 10.7 & 15119 & 7.0 \\
\hline Oct. & 15.2 & 31.6 & 23.40 & 10.7 & 43 & 1.0 & 8.1 & 9828 & 3.6 \\
\hline Nov. & 6.5 & 21.3 & 13.90 & 44.01 & 61 & 1.2 & 6.9 & 6791 & 1.6 \\
\hline Dec. & 4.6 & 15.1 & 9.80 & 59.83 & 75 & 0.9 & 4.8 & 5420 & 0.9 \\
\hline
\end{tabular}

The water can be pumped from deep well. The stable water table in this region is between $30-150 \mathrm{~m}$ after pumping few hours.

The well can de drilled by local driller, the price of drilling is about 5 dollars per meter.

PVC pipe is chosed as a main line to transfer water to the laterals. The length of main line is $295 \mathrm{~m}$.

The out-side diameter of it is $130.4 \mathrm{~mm}$ and the inside diameter is $110 \mathrm{~mm}$.

The following method can be used in determination of head loss in PVC pipes:

$$
h=\frac{L \times V^{2} \times K \times 1000}{d \times 2 g}
$$

Where, $\mathrm{L}=$ pipe length, $\mathrm{m}$.

$\mathrm{V}=$ Velocity of water inside the pipe, $\mathrm{m} / \mathrm{s}$.

$\mathrm{K}=$ friction loss factor $=0.017$.

$\mathrm{g}=$ acceleration due to gravity, $\mathrm{m} / \mathrm{s}^{2}$.

$\mathrm{d}=$ inside diameter, $\mathrm{mm}$. 
By Application above equation the head loss in main line is $1.47 \mathrm{~m}$.

Aluminum pipe is chosen to transfer water in the lateral lines.

The length of later line is $235 \mathrm{~m}$.

The outside diameter of the chosen pipe is $76 \mathrm{~mm}$, with $1.8 \mathrm{~mm}$ wall thickness. Therefore the inside diameter is $72.4 \mathrm{~mm}$.

Applying the above equation considering friction loss factor for aluminum pipe is 0.018 and 0.226 for one coupler.

To determine the head loss in a lateral with multiple outlets the head loss should be multiplied to a factor corresponding to the number of outlets (sprinklers) on the lateral, or in (14 outlets in this system) should multiplied to 0.37 (Aslyng, 1962).

Fourteen sprinklers will be in use with discharge of $1.61 \mathrm{~m}^{3} / \mathrm{h}$ for each sprinklers. Therefore RAIN BIRD 40B, 4.67mm inside diameter nozzle with pressure of 3.5 atmosphere can be used and $(15 \mathrm{~m} \times 18 \mathrm{~m})$ sprinkler area and $6 \mathrm{~mm} / \mathrm{nhr}$ application rate.

Evapotranspiration is estimated according to Jensen and Haise method (Piar et al. 1995) table 1.

\section{RESULTS AND DISCUSSION}

\section{Calculation of Sprinkler Irrigation System capacity:}

Table 1 shows the peak moisture use rate for the crops is $9.5 \mathrm{~mm} /$ day.

Considering the economical point of view only $70 \%$ of the peak moisture use rate $(9.5 \mathrm{~mm} /$ day) will be in use in calculating the capacity of the sprinkler irrigation system and is equal to:

$9.5 \times 0.7=6.65 \mathrm{~mm} /$ day.

Baars (1968) said that the economically justified capacity is of concern and a reasonable demand is that the installation completely meet the moisture requirement of the crops in $70-80 \%$ of the years. 
In this study the net area to be irrigated is $45700 \mathrm{~m}^{2}=4.75$ hectars. Therefore, the amount of water to apply for the whole area per day will be $45700 \times 0.00665=316 \mathrm{~m}^{3} /$ day.

$$
\left.=\frac{316}{14}=22.5 \mathrm{~m}^{3} / \mathrm{h} \text { (with } 14 \text { sprinkling hours } / \text { day }\right) \text {. }
$$

\section{Determination of total dynamic head (tdh) for the system:}

$\mathrm{tdh}=$ total static head + pressure head + friction head + velocity head.

Static head:

It is the vertical distance that pump must raise the water. The vertical distance from the water surface to the pump center line is called static suction lift.

In the case of deep well pump, the static suction lift is called the pumping head Fig. 2.

Pumping head $=$ static pumping head + drawdown.

Pumping head $=11.25+18.75=30 \mathrm{~m}$.

Static discharge head can be considered as the height of water pushing back on the discharge side of the pump.

The static discharge head in this system is $2.58 \mathrm{~m}$. Therefore the total static head equal to:

Pumping head + static discharge head $=30+2.58=32.58 \mathrm{~m}$.

Pressure head:

A sprinkler nozzle converts pressure head into velocity head, which carries the water out into its trajectory. The pressure (3.5) in atmosphere or kpa. necessary to operate the sprinkler should be converted into meter of head before adding to the other components to obtain the dynamic head.

Pressure head $=3.5 \times 10.33=36.16 \mathrm{~m}$. 
Friction head:

Water flowing in pipes is always accompanied by a loss of pressure due to friction. The degree of loss depends on the smoothness of the inside walls of the pipe, the diameter of the pipe, the viscosity of the fluid and the velocity of the water in the pipe. For this system the friction head is calculated $9.02 \mathrm{~m}$.

Therefore, the total dynamic head $(\mathrm{tdh})=$ Total static head + pressure head + friction head

$$
\begin{aligned}
& =32.58+36.16+9.02=77.76 \mathrm{~m} \text { of water column } \\
& \approx 78 \text { of water column } .
\end{aligned}
$$

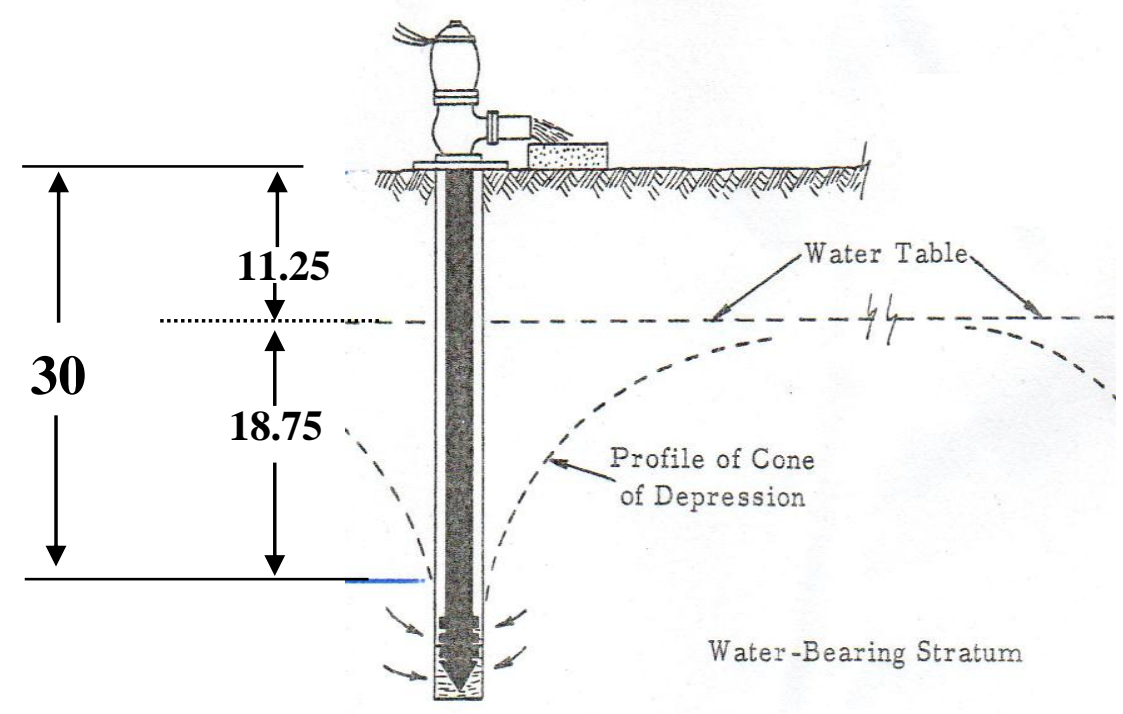

Fig. 2: Pumping head in deep-well pump

\section{Computing power Requirements:}

The pumping condition is usually the deciding factor in the selection of pump type, however, other things may be giving consideration, such as convenience in operation of the system is to be operated by owner, should more than one type adaptable. 
The water to this field should be pumped from a well in which the water level of the well when pumping is $30 \mathrm{~m}$ below ground surface.

Considering the characteristic curves for different type and sizes of submersible pump available from GRUNDFOS Company in Denmark, and remembering the quantity of water to be pumped $\left(22.5 \mathrm{~m}^{3} / \mathrm{h}\right)$, and the total dynamic head of $78 \mathrm{~m}$ of water column.

It has been seen that only SP 25 type and CR 30 type are convenient to pump water under the given condition with the maximum efficiency. To decide the convenient size or sizes from these two types, a certain calculation must be done:

The horsepower output of pump, or water horsepower (whp):

$$
\begin{gathered}
\text { whp }=\frac{g p m \times t d h \text { in } f t}{3960}=\frac{m^{3} / h \times t d h \text { in } m}{274} \\
\text { whp }=\frac{22.5 \times 78}{274}=6.4 h p=4.8 \mathrm{~kW}
\end{gathered}
$$

Break horsepower (bhp):

bhp can be obtained by dividing whp by pump efficiency expressed as decimal:

$$
\text { bhp }=\frac{w h p}{\text { effeciency }}
$$

Considering pump SP 25, the efficiency of the pump when its output is $22.5 \mathrm{~m}^{3} / \mathrm{h}$ is $67 \%$, Fig. 3 .

$$
\text { bhp }=\frac{6.4}{0.67}=9.6 h p=7.2 k W
$$




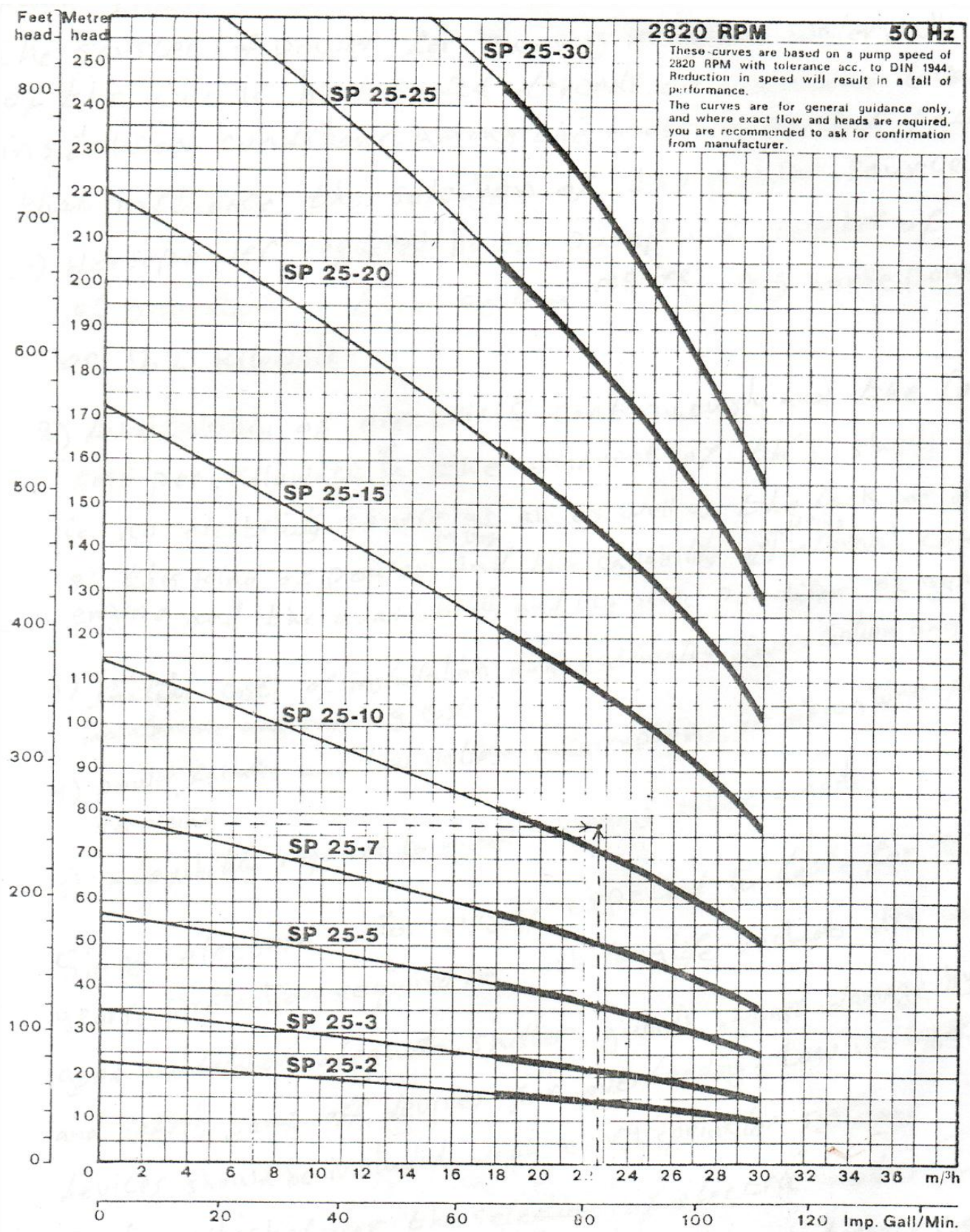

Fig. 3: Q-H curve of SP 25 pump

\section{Power source selection:}

The heart of any sprinkler irrigation system is the pump. Internal combustion engines and electric motors are the source of power for the pumping irrigation water. Which of the two is best suited depends on 
individual local installation conditions. Among the most important factors that influence the selection of the power source.

1. Horsepower required by the pump and number of hours of operation, this system requires 9.5 horsepower or 7.2 kilowatt.

2. Availability of electricity continuously and the local cost per kilowatt. In the district of this study there is no electricity source at all as well as the lack or deficit of this kind of power in Iraq. And the capability of using internal combustion engine and the availability and the price per liter of gasoline, should be considered.

3. Initial cost of installation and estimated depreciation and maintenance and running cost.

4. Power failures and low voltage interruptions, or down time for engine servicing.

5. Flexibility required to meet changing future needs.

Since electric motor may be expected to last for 20 to 30 years. Protection required for such long life includes dry mountings, good ventilation, adequate shelter, guards against damage by rodents and safety shut-off device for overloading, low voltage. Such devices should be included with every sprinkler system.

Factors which favor the selection of electric motors including ease of operation, relatively long life, low maintenance costs, dependability and the efficiency of electric motors is high.

For these reasons an electric motor is selected to drive the pump used for pumping water to this sprinkler system.

As mentioned there in no electricity source in the district of this study.

Solar radiation energy is suggested to provide the system with electricity. Depending to the solar radiation intensity and sunshine time are too long in this region (Table 1).

\section{The economy of the solar energy:}

A solar cell manufacturer company produces cells of dimensions $85 \mathrm{~cm} \times$ $115 \mathrm{~cm}$ and each cell produce electrical power of 100 watt with price of 500 dollars or 5dollars per watt. And this include the cell price, 
maintenance for one year and the installation price and insurance for 20 years of the life of cells.

The power requirement of the system is $7.2 \mathrm{kw} \approx 8 \mathrm{kw}$.

Number of cell pieces $=\frac{8000}{100}=80$ pieces

The total cost of the solar energy $=80 \times 500=40000$ dollars.

Or $5 \times 8000=40000$ dollars.

Therefore the initial cost is too high.

Considering the life of the system 20 years.

$\therefore$ The fixed cost per year is $\frac{40000}{20}=2000$ dollars

The running cost of the solar energy is too low.

Because of the pumping the water for the system will be during the sun shine (day) time. It does not need batteries for storing energy.

The cost of well drilling and sprinkler system should be added to the power producing.

The total cost of the project that must be considered included costs for water supply, pump, power, distribution system and special equipments.

Where water supply cost $=5 \times 200=1000$ Dollars.

Pump cost $=3000$ Dollars.

Power cost $=40000$ Dollars.

Distribution system cost $=4000$ Dollars.

Total project cost $=1000+3000+40000+4000$

$$
=48000 \text { Dollars. }
$$

Regarding production (yield/hectar) of irrigated planting crops in Iraq, investment in such projects is good.

\section{REFERENCES}

Al-Fakhry, A. K., 1974. Improvement of dry Land farming in northern Iraq. Paper presented at the scientific conference on. Recent stages and prospects of Agricultural Mechanization in Developing countries, Leipzig GDR, July $15 \mathrm{t}-10^{\text {th }}$. 
Aslyng, H.C., 1962. (Danish). Vannding i jordbruget. Den Kgl. Veteinear og Labohojskole i Danmark 124P.

Baars, ir.C., 1968. Calculation of the advisable capacity of sprinkler system, based on meteorological data, 54P.

Choudhury. M.S., Laith. K. . I and A.K. AL-Fakhry, 1977. Mechanized tillage dry farming in Iraq. Agricultural mechanization in Asia, Vol. VIII. No.2, pp 11-16.

Pair, C.H., W.W.Hinz, C. Reid and K.R. Frost (editors), 1995. Sprinkler Irrigation, Mary Land, U.S.A., 615P.

الملخص العربحي

استخدام الطاقة الشمسية لضخ الماء في نظام الري بالرش

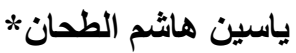

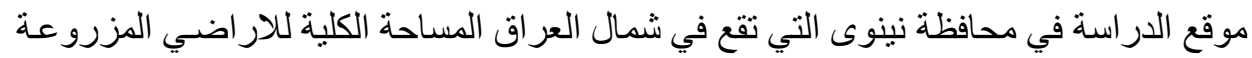

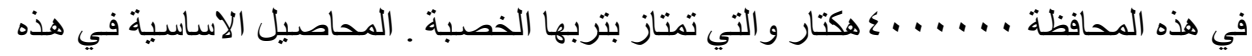

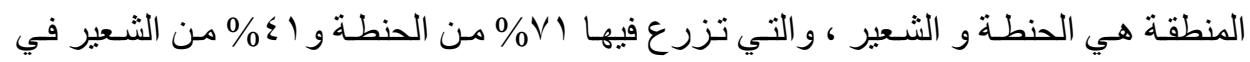

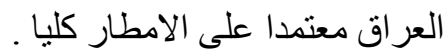

نظر الثحة الامطار و عدم كفايتها خـلال السنوات العشرة الماضية معظم الفلاحين لم يحصدوا

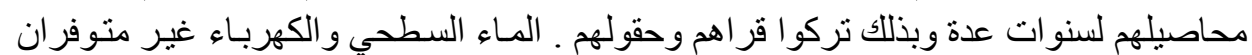

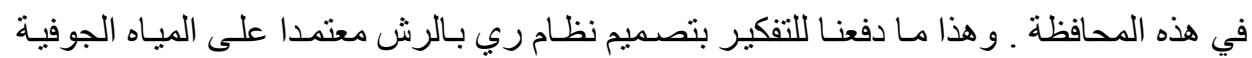

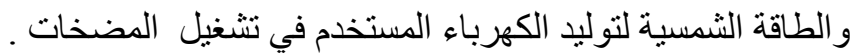

يمكن استخدام هذا النظام كري تكميلي مع المحاصيل الثنتية (الحنطة و الثنعير )، كما انه يعطي

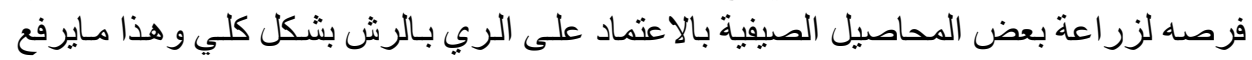

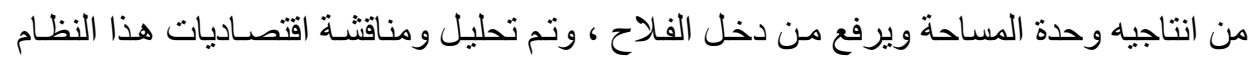

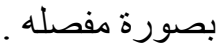

*قسم المكائن والالات الزراعية ـ كلية الزراعة و الغابات جامعة الموصل /العراق. 